\title{
On the Negative Consequences of Outsourcing
}

\author{
Duczon Árpád \\ Faculty of Economics, University of Pécs
}

\begin{abstract}
Outsourcing is mostly used as a tool to reduce a company's costs. While outsourcing works well in some areas, such as call centres or shared service centres, more and more, the negative consequences of outsourcing are highlighted in other areas such as manufacturing. What causes this disconnect? I argue that a company has some key competencies that, when outsourced, dramatically increases the bargaining power of its contract manufacturer, allows it to take on more functions of the original manufacturer than first intended and ultimately enables it to act as a direct competitor. These key competencies include manufacturing while it excludes shared services, hence the above disconnect. Companies must identify the danger that outsourcing a given activity causes: How easy it is to replicate the company using only this one skill that the company wishes to outsource? Beyond this, several good practices are shown that help diminish the danger posed by outsourcing, such as outsourcing products only at a certain point in their lifecycle or spreading the manufacturing among several companies.

Keywords:
\end{abstract}

\section{Introduction}

Over the past period, the judgement of outsourcing has changed. In the 1990s and 2000s, it was a clear, logical response to changing market conditions (Aron \& Singh, 2005; Krajewski et al., 2010) and was treated as a cost-cutting measure needed hardly any strategic considerations. However, nowadays, more and more authors draw the attention to its negative consequences (Pisano \& Shih, 2012) and a reverse, insourcing process has started.

The purpose of the study is to demonstrate the risks of outsourcing for a company. By identifying the risks, it is possible to determine the roots of the hazards and thus provide solutions to how they can be mitigated or eliminated.

\section{Literature}

\section{1- Benefits of outsourcing}

Offshoring is an activity, in particular for the United States, Japan and Western Europe, whereby different functions of the company are taken to another country to take advantage of low wages and operating costs. (Lach, 2012)

It is more difficult to define the concept of outsourcing, as the authors use it differently in literature. According to Krajewski et al. (2010), outsourcing is paying the suppliers or distributors for carrying out some kind of activity. Lach (2012) defines is as to hire another company to perform an activity that was earlier performed by the outsourcing company. Lagace (2004) points 
International Conference on Research in Management \& Economics

Serbia | Belgrade | December 15-17, 2018

out that the concepts of outsourcing and offshoring have often become blurred and they have been used as synonyms for one another.

As this paper intends to deal with the long-term implications of outsourcing, the definition by Lach (2012) is going to be used below instead of the broad interpretation by Krajewski et al. (2010).

In the following, the term outsourcing will refer to the practice when an activity of a company that you have previously carried by it is transferred to another economic operator, irrespective of its geographic location.

Accordingly, for example, I note that the view of Craumer (2002) whereby the change or renewal may be based on the idea that a new type of task is assigned to a another more competent company rather than the company would develop its competence in the relevant field is true, but I do not call it outsourcing in the narrow sense of Lach's definition (2012).

Outsourcing may have multiple benefits if it is implemented well. One of the main considerations behind it is that the cost of labour may be reduced if the company outsources into a country with lower expected employee wages (Krajewski et al., 2010). Although the lower-paid foreign workforce is generally characterised by lower productivity (Markides-Berg, 1988), the correlation, in my opinion, is not linear. In other words, although in the year 2017, the average wages adjusted for purchasing power parity in Hungary accounted for about 37 per cent of that of the United States (OECD 2018), it would be a serious exaggeration to claim that American employees are three times more productive than their Hungarian counterparts, especially bearing in mind that several US companies have their service centres in Hungary.

Outsourcing, however, has advantages other than just reducing labour costs. They include the reduction in logistics costs, if the company can get closer to the buyers. It may also be advantageous that different countries may have the conditions of competition. Taxes and customs duties, labour laws or the negotiation power of trade unions may also vary greatly. (Aron \& Singh, 2005; Krajewski et al., 2010).

They all reduce costs and thereby increase the profits of the company. This justifies the spread of outsourcing. However, beside the benefits, it also has serious negative consequences, and the next subchapter is focusing on this issue.

\section{2- Risks of Outsourcing}

In addition to the advantages outlined in the previous subsection, there are also risks involved in outsourcing. The purpose of this subsection is to present them. This helps to identify the cause of the problem.

\section{2-1 Doubts about short-term return}

It is far not guaranteed that outsourcing will redeem the hopes associated with it. According to Craumer (2002), while in 1990 almost 80 per cent of companies were satisfied with the results of their outsourcing, this tendency fell down to 54 per cent by 2000.

In fact, the effective implementation of outsourcing is by no means guaranteed at the outset and competition can erode benefits (Arruñada \& Vázquez, 2006). Changes in the duties and taxes 
International Conference on Research in Management \& Economics

Serbia | Belgrade | December 15-17, 2018

levied can decrease or offset the profit from reduced logistical and labour costs. (Markides \& Berg, 1988).

Over time, the standard of living begin to rise in low-cost countries as well and thus the country's competitive advantage is lost, for example, such as in the case of China (Sun, 2017). China used to be a popular outsourcing destination country for the United States (Sun, 2017), but Chinese wages increased from 29,229 yuan to 74,318 yuan between 2008 and 2017 (Statista, 2018), which is equivalent to a nominal annual wage increase of approximately 17 per cent and, in my opinion, this demonstrates the short-term nature of labour cost-saving power of outsourcing really well. At the same time, these investments, by virtue of their character, are not so liquid, and it is therefore difficult to always relocate the activity concerned to the site of the lowest possible cost.

It also reduces the profitability of outsourcing that the cost of carrying out the task is replaced by the expenses involved in quality assurance and quality monitoring (Gomes-Casseres, 2009), more generally the handling of agent-client issues.

Even competent outsourcing can also reduce efficiency (Craumer, 2002), through the extension of supply chain. Craumer (2002) points out that if several companies are involved in the same task, it is in the interests of each company to accumulate security stocks. These security stocks reserves would not be created if the supply chain were integrated throughout.

\section{2-2 Difficulty in planning the strategy}

Another major problem is the difficulty of strategic planning. It is not easy to find a common and frequently used definition for strategy in the literature.

Various authors (Krajewski et al., 2010; Pisano, 2015; Porter, 1996; Red, 2010) place emphasis on different aspects. According to Krajewski et al. (2010), strategy outlines a guideline that connects the company's activities as a framework. In Porter's view (1996), strategy is to choose what activities the company should do differently compared to its competitors. According to Pisano (2015), they are such mutually reinforcing activities that are aimed at achieving a particular competitive objective. Red's opinion is (2010) that strategy is a set of actions that create a dominant economic position through the use of key capabilities.

While definitions show a varied picture, some common features can be specified. Accordingly, this paper identifies three main characteristics of the strategy based on the above authors (Krajewski et al., 2010; Pisano, 2015; Porter, 1996; Red, 2010):

1. Strategy consists of several activities.

2. These activities are coordinated by the strategy to a set of coherent, mutually reinforcing activities.

3. The task of strategy is to achieve some objective, more precisely, to reach some economic goal in the economic field concerned.

Therefore, since strategy is a combination of mutually beneficial activities, if the company outsources an activity, it cannot be expected that it can respond to the changing market conditions with its earlier speed (Craumer, 2002); it cannot deploy the activity concerned to a dynamically changing strategic objective. The more activities are outsourced, the greater the 
International Conference on Research in Management \& Economics

Serbia | Belgrade | December 15-17, 2018

inefficiency of the corporate strategy, and the number of activities that are difficult to change in the short term will be.

\section{2-3 A The bargaining power of subcontractors}

In my opinion, one of the greatest risks of outsourcing is that is that the bargaining power of the company contracted for manufacturing is increasing incredibly (Markides \& Berg, 1988). Since the outsourcing company degrades the capacity required to carry out the outsourced activity, it is obviously losing its ability to perform the task over time. This is the critical moment for the increase of the subcontractor's bargaining power.

The subcontractor can then take advantage of the fact that it has a control overs critical task of the outsourcing company that does not have the chance to resource it or transfer it to another subcontractor in the short term. The subcontractor can use this influence to claim a larger share of the profits, and if its claim is not met, it can cause huge damage, for example by refusing to extend the contract.

Similarly, the subcontractor becomes aware of the client's business secrets, or at least part of them (Arruñada \& Vázquez, 2006), but it only has an economic interest to keep them if the relationship is long-term since in that case the subcontractor wants to preserve the competitive edge of the company and thereby the client's profits and ultimately his own safety.

However, if the relationship is short-term, then the subcontractor is interested in selling the knowledge accumulated for him at the end of the contract to the client's competitors. Even if the contract of assignment is thorough and enforceable, a competitor may have the means to offer a sum that that will earn the subcontractor profits in addition to the cost of litigation. If a competitor is willing to offer such an amount of money for the knowledge, then the profit from this knowledge will surpass even that amount, and thus the client company's fundamental interest is to protect this secret. The bid itself, even if the subcontractor refuses it, rearranges the bargaining power for the benefit of the subcontractor.

The increase of the bargaining power of the subcontractor and the degrading of the company's competence to perform the activity themselves can lead to a situation where the subcontractor will get more and more functions.

Arruñada and Vázquez (2006) points out that Chinese companies such as Lenovo or the Shanghai Automotive Industry Corporation have been operating as subcontractor manufacturers for various US and European companies: Lenovo produced for IBM while Shanghai Automotive Industry Corporation was a subcontractor for Mercedes-Benz and for Volkswagen. By getting the various corporate functions, however, instead of assembling, some smaller parts were manufactured locally, then they manufactured bigger and bigger and more and more critical parts for their clients, until they accumulated a critical mass of knowledge and skills to build their own brand and, breaking away from their clients, they appeared on the market as competitors for their former clients.

It is evident that these companies would not have been able to build their own production and brand on their own. 
International Conference on Research in Management \& Economics

Serbia | Belgrade | December 15-17, 2018

In this respect, this process is very similar to disruptive innovation by Christensen et al. (2015), where an emerging company exploits a market niche that companies currently competing do not deal with and thus do not identify the new company as a competitor. If they did identify it as a competitor, they would probably try to banish it from the market with some sort of counter strike (Porter, 1993). However, as they do not identify it as their competitor, it will be able to build up its own brand, consumer base and resources in this emerging market segment unhindered. The critical step here is when the company strengthened this way starts expanding into the market of companies previously not treating as a competitor. At this point the counter strike has already been delayed and is unlikely to be effective. A typical example of such disruptive innovation is Netflix that has become a major player in its market as a company not identified as a competitor by Blockbuster, which has gone bankrupt since then (Christensen et al., 2015).

The analogy is quite obvious. The client company does not identify the subcontractor company as a potential competitor and therefore transfers data, knowledge and technology safeguarded from its competitors, which it identifies as valuable resources (Collis \& Montogomery, 1995) its long-term strategy is based upon. And nothing else but the client company's wrong assessment of the situation provides the subcontractor the opportunity to act as a competitor.

\section{2-4 Long-term implications}

The long-term implications of outsourcing are quite evident in the United States. Pisano (2015) argues that outsourcing destroys the ability to innovate, as developing a new product requires a close collaboration between design and implementation. (Pisano, 2015) In other words, if the current product is outsourced, it is impossible to design and manufacture newer products (Markides \& Berg, 1988; Pisano, 2015).

Pisano and Shih (2012) refer to the phenomenon as industrial common when suppliers, buyers, competitors, skilled workforce, infrastructure and universities reach a the critical mass in a geographic area serving a particular industry. The industrial common is formed because a company in a particular area attracts suppliers and skilled workers, so when a competitor enters this market, it is also a logical step to settle here and tap the competitor's resources.

Accordingly, the growing demand by companies attracts more skilled workers and suppliers to the area. Later universities training the relevant professionals can also settle in this area. It is evident how this self-strengthening process gains momentum. (Pisano \& Shih, 2012)

Considering the process of development, it is also immediately evident why outsourcing goes beyond one company. As a result of outsourcing, the above process stops or even reverses (Pisano \& Shih, 2012). When companies leave an area, suppliers and skilled workers will also move forward. The decline in labour supply and the increasing bargaining power of suppliers reinforces the competition in the industry concerned (Porter, 2008 [1979]).

This may be an additional incentive for these companies to outsource. Just as the emergence of the industrial common, its decline is also a self-strengthening process.

The loss of innovation ability and the decline of the industrial common jointly lead to the nation's loss of ability in the area. Such a process has taken place, for example, in the solar panel market, which although had been planned in the United States, in the absence of additional industries in 
International Conference on Research in Management \& Economics

Serbia | Belgrade | December 15-17, 2018

the United States had to be outsourced, therefor the Asian industry grabbed the production of solar panels as well. (Pisano, 2015).

\section{The root of the problem}

Outsourcing works very well in some areas, the benefits outlined above prevail and the disadvantages are minimal, such as service centres or call centres (Pisano \& Shih, 2012). In other activities, the disadvantages are more apparent, such as in case of production.

What causes this break? The risks outlined above help to answer this question. In most cases, outsourcing some activities initially reduces costs and offer benefits. For some activities, however, long-term processes, as described in the previous subsection, begin to unfold damaging the client and to the whole industry.

The company has some core capabilities, which, if outsourced, enables the subcontractor company to act later on as a competitor in the original manufacturer's market. (Arruñada \& Vázquez 2006; Markides \& Berg, 1988, Rappaport; 2009)

The associated company functions such as marketing, customer service or sales can easily deployed around manufacturing competence.

However, in the reverse case, a service centre or call centre detached from the core activity cannot create value; it is difficult to create the abilities to compete with the original producer.

According to the above, the strategic decision about outsourcing should be part of an analysis that raises the question: How difficult it is for the subcontractor to develop the outsourcing company's core activities based on the activity outsourced?

If the answer is that it is relatively easy to rebuild the company with this ability, than it is a key or core process that can only be resourced with great caution. In the next chapter, I suggest several solutions that reduce the risk of outsourcing a key process.

However, if the answer is that in the possession of this capability the company's main business is not threatened by any risk, the activity can indeed be outsourced based on profitability considerations.

Production, for example is such a core competence. Even if it is the corporate functions rather than production itself create most of the added value, control of product is ultimately of paramount importance. Termination of supply, for example as a result of conflict between the subcontractor and the original manufacturer, causes a direct emergency situation to the company, while some missed calls to a customer service could never have the same effect.

In addition, according to Pisano (2015), in the absence of innovation, the company is forced to become a follower on the market of innovative products.

Gomes-Casseres (2009) presents how outsourcing has become a wide-spread practice through industries. In my view, it is the lack of strategic analysis and the identification of core capabilities outlined above, has led to the spread of outsourcing even in industries and activities where, in the long run, it is against the interest of the company or industry. 
International Conference on Research in Management \& Economics

Serbia | Belgrade | December 15-17, 2018

\section{Possible solutions}

There are a number of good practices in the literature that control the risk of outsourcing and hinder the increase of the supplier's negotiating power (Craumer, 2002; Arruñada \& Vázquez, 2006; Pisano \& Shih, 2012; Porter, 1993; Venkatesan, 1992).

Before presenting them, however, I would like to emphasize once again that, since, in my view, the root of the problem is the outsourcing and degradation of core competencies, outsourcing should therefore be a strategic decision that takes into account how much the access to the capacity concerned will facilitate the contractor to enter the market as a potential future competitor.

The good practices presented here can therefore be really useful if the activity to be outsourced has been identified as a core competence, which, although it can reduce costs, it can also represent a possible future threat for the company.

For example, if outsourcing of production is inevitable, it is a good idea, as Venkatesan (1992) suggests, if the company identifies the critical elements of its product. Outsourcing some general elements can result in further cost reductions if these general elements become more general and homogeneous and thus the competition of subcontractor producers in their market becomes even fiercer. (Venkatesan, 1992)

Keeping the critical elements makes sure that the company's true critical competences are not lost, while the contractors' can initiate the acquirement of further functions. This behaviour should be expected and the client company has to be committed to the production of core products by itself over the long term.

Similary to Venkatesan (1992), Arruñada and Vázquez (2006), attempted to resolve the loss of innovation ability as envisioned by Pisano's (2015).

According to Arruñada and Vázquez (2006), the latest generation products represent the critical elements in manufacturing. Keeping them in-house, can prevent manufacturing from distancing from design as outlined in Pisano's model (2015), thus it does not damage the company's innovation ability.

However, the older product types at later stages of their life cycles can be outsourced (Arruñada \& Vázquez, 2006). The additional benefit of this approach is that the innovative features of older product types are likely to have already been copied by competitors, therefore the moral hazard associated with the subcontractor and the risk of disclosure of trade secrets can be minimized. 
International Conference on Research in Management \& Economics

Serbia | Belgrade | December 15-17, 2018

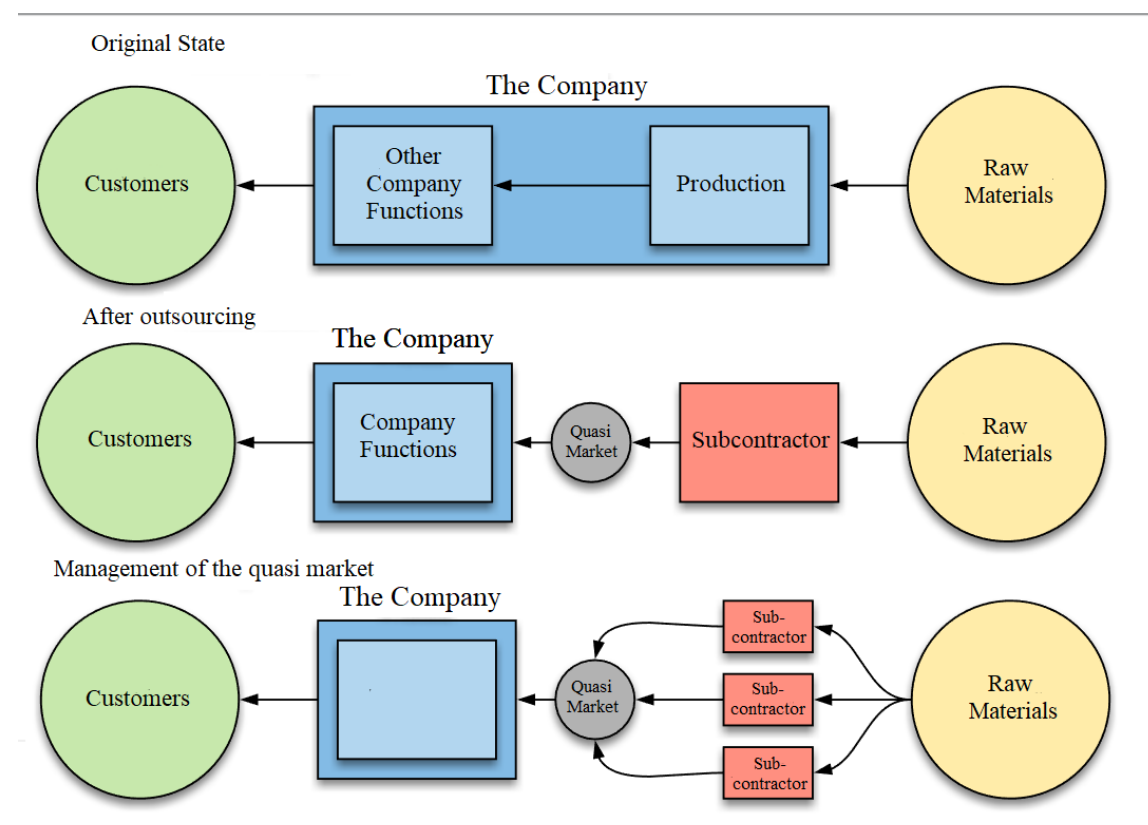

Figure 1: Reducing the contractors' bargaining power by using Porter's (1993) five forces. Source: edited by the author

Starting from the point of view of bargaining power, Porter (1993) uses five forces to reduce the negotiating power of suppliers (Porter, 1993). The negotiating power of the subcontractors lies in the fact that they are in a monopoly position in the artificially created quasi-market supplying the original manufacturer. This monopoly can be broken, for example, by using several subcontractors or by spreading the manufacturing process to more than one manufacturer. This is illustrated in Figure 1.

As a result, the subcontractor's effort to increase prices is prevented by the threat of other manufacturers, and refusing to perform result in the loss of only a part of the production. At the same time, spreading the manufacturing process to several manufacturers means that the transfer of trade secrets related to a partial-process does not represent as great threat for the original manufacturer as the transfer of all the trade secrets involved in the complete production. A similar principle prevails in another suggestion by Arruñada and Vázquez (2006) where the company retains a part of its production capacity, i.e. functionally acts as a competitor of its own subcontractor. This also helps to retain its innovation capability and manufacturing competence.

\section{Conclusion}

To summarize, the loss of the core competencies of the company is a major threat to its core business. The purpose of this study was to present the benefits and highlight the threats involved in outsourcing. The most significant ones of the latter in manufacturing include the loss of innovation capacity and the increase in the bargaining power of the subcontractor.

The key role of production lies in the fact that it is an activity included in the core competencies of the company. When it is available for a company, it can easily build up additional corporate 
International Conference on Research in Management \& Economics

Serbia | Belgrade | December 15-17, 2018

features which allow the subcontractor to act as a competitor. In general, however, before outsourcing any activity, it is important that strategic decision-making should include risk assessment regarding the loss caused by a possible failure to complete the order by the subcontractor, the loss of trade secrets, and the damage involved in the moral risk associated to the subcontractor.

The good practices presented here, the use of several subcontractors, keeping a part of the capacity and the production of the latest products by the original producer will ultimately help to make sure that it should not be a realistic goal to the subcontractor to take over the full production and to compete with the original manufacturer. The most important task of producers is to develop long-term relationships with subcontractors. If taking over the whole production is not a realistic goal and the subcontractor can rely on cooperation with the original manufacturer in the long run, and then the entire value chain will indeed serve the keeping of the original producer's competitive advantage, as it is also a long-term interest of the subcontractor as well.

\section{References}

1. Aron, R., Singh, J. V. (2005). Getting Offshoring Right. Harvard Business Review, 83(12), pp. 135-144.

2. Arruñada, B., Vázquez, X. H. (2006). (2006): When Your Contract Manufacturer Becomes Your Competitor. [online] Elérhető: https://hbr.org/2006/09/when-your-contract-manufacturerbecomes-your-competitor [Utolsó letöltés: 2018. 09. 11.]

3. Collis, D., Montgomery, C. A. (1995). Competing on Resources: Strategy in the 1990s. Harvard Business Review, 73(7), pp. 118-128.

4. Craumer, M. (2002). How to Think Strategically About Outsourcing. Harvard Management Update, 7(5). [online] Elérhető: https://hbswk.hbs.edu/archive/how-to-think-strategicallyabout-outsourcing [Utolsó letöltés: 2018. 09. 11.]

5. Christensen, C. M. - Raynor, M. E. - McDonald R. (2015):What is disruptive innovation? Harvard Business Review,93(12), pp. 44-55.

6. Gomes-Casseres B. (2009). Outsourcing: Where Will You Draw The Line? [online] Elérhetö: https://hbr.org/2009/08/outsourcing-where-will-you-dra [Utolsó letöltés: 2018. 09. 11.]

7. Krajewski, L. J., Ritzman, L. P., Malhotra, M. J. (2010): Operations management. Upper Saddle River, NJ: Pearson.

8. Lach, (2012): 5 Facts About Overseas Outsourcing: Trend Continues to Grow as American Workers Suffer. Centre for American Progress.

9. Lagace, M. (2004): The Outsourcing Revolution. Harvard Business School: Working Knowledge: Business Research for Business Leaders.

10. Markides, C. C., Berg, N. (1988). Manufacturing Offshore is Bad Business [online] Elérhető: https://hbr.org/1988/09/manufacturing-offshore-is-bad-business [Utolsó letöltés: 2018. 09. 11.] 11. OECD (2018): Average wages. [online] Elérhető: https://data.oecd.org/earnwage/averagewages.htm [Utolsó letöltés: 2018. 11. 07.]

12. Pisano, G. P., Shih, W. C. (2012). Does America Really Need Manufacturing? Harvard Business Review, 90(3), pp. 94-103. 
International Conference on Research in Management \& Economics

Serbia | Belgrade | December 15-17, 2018

13. Pisano, G. P. (2015). You Need an Innovation Strategy. Harvard Business Review, 93(6), pp. 44-54.

14. Porter, M. (1993). Versenystratégia. Budapest: Akadémiai Kiadó.

15. Porter, M. E. (1996): What is strategy? Harvard Business Review, 74(11), pp. 61-78.

16. Porter, M. E. (2008, [1979]): The five competitive forces that shape strategy. Harvard Business Review, 86(1), pp. 78-93.

17. Rappaport, A. (2009). Outsourcing Isn't a problem for Silicon Valley But Is For Detroit. [online] Elérhető: https://hbr.org/2009/10/outsourcing-isnt-a-problem-for [Utolsó letöltés: 2018. 09. 11.]

18. Sun, Y. (2017).

19. Venkatesan, R. (1992). Strategic Sourcing: To Make or Not To Make [online] Elérhető: https://hbr.org/1992/11/strategic-sourcing-to-make-or-not-to-make [Utolsó letöltés: 2018. 09. 11.]

20. Vörös, J. (2010).

21. Statista (2018). Average yearly wages in China from 2008 to 2017 (in yuan). [online] Elérhető: https://www.statista.com/statistics/743522/china-average-yearly-wages/[Utolsó letöltés: 2018. 11. 08.] 